DOI https://doi.org/10.30525/978-9934-26-184-8-12

\title{
РЕГЕНЕРАЦІЙНИЙ ПОТЕНЦІАЛ РІЗНИХ СОРТІВ ВИНОГРАДУ В КУЛЬТУРІ ТКАНИН І ОРГАНІВ IN VITRO
}

\author{
Зеленянська Н. М. \\ доктор сільськогосподарських наук, \\ стариий науковий співробітник, \\ заступник директора з науково-інновачійної діяльності \\ Національний науковий центр \\ «Інститут виноградарства і виноробства \\ імені В. С. Таїрова» \\ Національної академії аграрних наук Украӥни
}

\section{Самофалов М. 0.}

аспірант

Національний науковий центр «Інститут виноградарства і виноробства імені В. С. Таїрова» Національної академії аграрних наук України м. Одеса, Україна

Для створення вихідного, сертифікованого садивного матеріалу винограду (вільного від вірусної та бактеріальної інфекціi) у сільськогосподарській науці i практиці широко застосовують методи культури тканин і органів in vitro. Вони дозволяють повніше реалізувати біологічний потенціал рослинного організму у процесі розмноження, зберегти і прискорити відтворення рослин бажаних генотипів. Метод культури тканин $\mathrm{i}$ органів in vitro дозволяє скоротити строки розмноження нових сортів і форм винограду у 4-5 разів, виробничі площі, збільшити коефіцієнт розмноження, використовувати у роботі невелику кількість вихідного матеріалу.

В основі цього методу лежить індукція органогенезу 3 ініціальної бруньки на штучних поживних середовищах в умовах культуральних приміщень. Цей процес відбувається в три та більше етапів. Ці етапи включають: 1 - введення експлантів в 
культуру in vitro; 2 - розмноження пагонів у культурі in vitro; 3 - одержання рослин із коренями та їх попередня адаптація до умов відкритого грунту; 4 - висаджування рослин [1, с. 23].

Однією 3 визначальних умов застосування методів in vitro $\epsilon$ склад та якість поживного середовища для введення в стерильну культуру і вирощування мікроклонів. Склад і фізичні властивості поживного середовища впливають на приживлюваність ініціальних експлантів, визначають початок проліферації пазушної бруньки, ризогенезу, приживлюваності ініціальних експлантів. Дослідження багатьох авторів виявили, що сорти винограду по-різному проявляють себе в культурі in vitro, i склад поживного середовища необхідно підбирати 3 урахуванням сортової специфіки. Для розмноження більшості сортів і клонів винограду in vitro застосовують поживні середовища на основі середовища Мурасіге i Скуга (MS). Загалом до його складу входять макросолі, мікросолі, хелат заліза, хлорид кальцію, вітаміни, індолілоцтова кислота (IOK), 6-бензиламінопурин (6-БАП), сахароза та агар [1, с. 24].

Проте, 3 погляду прояву регенераційних властивостей ініціальних експлантів винограду та подальшого розвитку мікроклонів, існують різні думки щодо кількості та співвідношення у поживному середовищі фітогормонів, його консистенції. Одержані результати досліджень часто є суперечливими і потребують подальшого вивчення. Крім того, ці питання набувають великої актуальності у зв'язку з адаптацією мікроклонів винограду до умов in vivo [2, с. 21].

3 огляду на вищенаведене метою нашої роботи було визначити регенераційний потенціал підщепних i технічних сортів винограду в культурі тканин і органів in vitro на різних типах поживних середовищ.

Матеріалом для досліджень були одновічкові чубуки сортів винограду Добриня, Гарант (підщепні) та Ярило (технічний).

Всі роботи, пов'язані з розмноженням винограду в культурі тканин і органів in vitro, здійснювали в асептичних умовах ламінарних та культуральних боксів, обладнаних ультрафіолетовими опромінювачами. Температура повітря в культуральному боксі дорівнювала $24-25^{\circ} \mathrm{C}$, фотоперіод - 16 год., освітлення $2500-3000$ лк., вологість повітря $60-70 \%$ [2, с. 11]. 
Ініціальні експланти винограду культивували на модифікованих поживних середовищах, за основу яких взято поживне середовище MS. Поживне середовище MS готували за прописом, після чого додавали інші компоненти.

Схема досліду була наступною:

Контроль 1 - MS + 0,3 мг/л IОК, 0,2 мг/л БАП;

Контроль 2 - MS + 0,6 мг/л IОК, 0,5 мг/л БАП;

Варіант 1 - MS + 0,3 мг/л ІОК, 0,2 мг/л БАП + Радіфарм 2,5 мл/л;

Варіант 2 - MS + 0,6 мг/л ІОК, 0,5 мг/л БАП + Радіфарм 2,5 мл/л;

Варіант 3 - MS + 0,3 мг/л ІОК, 0,2 мг/л БАП + Clonex gel;

Варіант 4 - MS + 0,6 мг/л ІОК, 0,5 мг/л БАП + Clonex gel;

Варіант 5 - MS + 0,3 мг/л ІОК, 0,2 мг/л БАП + агроперліт (1:1);

Варіант 6 - MS + 0,6 мг/л ІОК, 0,5 мг/л БАП + агроперліт (1:1);

Варіант 7 - MS + 0,3 мг/л ІОК, 0,2 мг/л БАП + вермікуліт (1:1);

Варіант 8 - MS + 0,6 мг/л ІОК, 0,5 мг/л БАП + вермікуліт (1:1);

Варіант 9 - MS + 0,3 мг/л IOK, 0,2 мг/л БАП + (агроперліт + вермикуліт) (1:1:1);

Варіант $10-\mathrm{MS}+$ 0,6 мг/л ІОК, 0,5 мг/л БАП + (агроперліт + вермикуліт) (1:1:1).

Для желювання середовищ використовували агар-агар у кількості 7,0 г/л (для варіантів 1 - 4) та 6 г/л (для варіантів 5 - 10). Всі поживні середовища стерилізували шляхом автоклавування під тиском 1 атм. протягом 15 хв.

Протягом 30 діб культивування ініціальних експлантів проводили обліки проліферації пазушної бруньки (\%) та ризогенезу (\%).

Результати проведених досліджень показали, що розвиток пазушних бруньок ініціальних експлантів винограду активніше розпочиналися у контрольних варіантах всіх досліджуваних сортів. Так на 10 день досліджень у сорту Добриня 5,5 (К. 1) та 38,5 (К. 2)\% ініціальних експлантів характеризувалися проліферацією пазушної бруньки, у сорту Гарант проліферацією пазушної бруньки характеризувалися 6,7 та 10,5\% ініціальних експлантів, у сорту Ярило - тільки 4,0\% на поживному середовищі контролю 2. Серед дослідних варіантів на 10 день досліджень 
розвиток пазушної бруньки відмічали тільки у сорту Гарант на поживних середовищах варіантів 5 (16,0\%), 6 (2,0\%) i 9 (4,5\%).

Процес ризогенезу розпочинався на сьомий день досліджень. В ініціальних експлантів сорту Добриня початок ризогенезу відмічали у $3(7,7 \%), 9(4,5 \%)$ та 10 (16,7\%) варіантах, у сорту Гарант - у контролі 2 (15,8\%), 9 (9,1\%) та 10 (39,1\%) варіантах, у сорту Ярило - у $3(29,4 \%)$ та 4 (28,6\%) варіантах.

Повні обліки проліферації пазушних бруньок та ризогенезу ініціальних експлантів винограду проводять на 30 день досліджень. Отримані результати показали, що найбільше одновічкових чубуків з проліферацією пазушної бруньки було у контролі 1, 2 та дослідних варіантах 5, 6 (Рис. 1). У середньому відсоток чубуків із розвиненою пазушною брунькою дорівнював $60,0-67,0 \%$ для сортів Добриня і Гарант та 56,0 - 58,0\% для сорту Ярило. У всіх інших дослідних варіантах кількість чубуків із проліферацією пазушної бруньки була меншою і знаходилася на рівні 30,0 - 40,0\%. Хоча слід відмітити, що у подальшому проліферація пазушної бруньки чубуків дослідних варіантів збільшувалась майже до рівня контрольних варіантів, але такі показники відмічали ближче до 35-40 доби.

Найкращі результати щодо активності ризогенезу були відмічені у всіх сортів на поживних середовищах з агроперлітом (78,0 - 86,0\%), сумішшю агроперліту і вермикуліту $(80,0-86,0 \%)$, Clonex gel $(78,0-82,0 \%)$ та обох контролях $(58,0-80,0 \%)$. Непогані результати за даним показником було отримано й у варіантах 4, 6, 7 - це 62,0 - 73,0\%.

Але слід відмітити, що в ініціальних експлантів винограду контрольних варіантів утворювалося по $2-3$ корені, які у подальшому набували більшої довжини, проте не були розгалуженими, у ініціальних експлантів винограду дослідних варіантів, навпаки, коренів утворювалося більше (5 - 8 шт.), вони мали велику кількість коренів другого і навіть третього порядків, відповідно і їх довжина була меншою. Цей факт $є$ надзвичайно важливим для переведення мікроклонів винограду з умов in vitro в умови in vivo. 


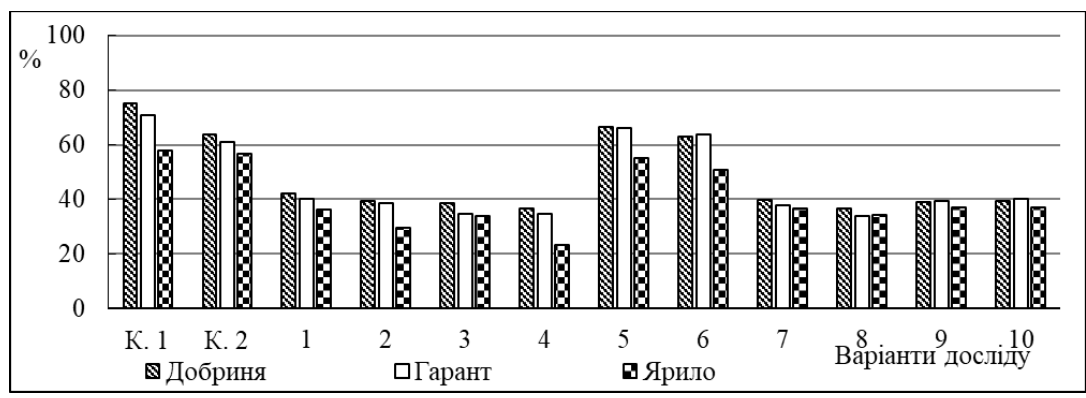

I

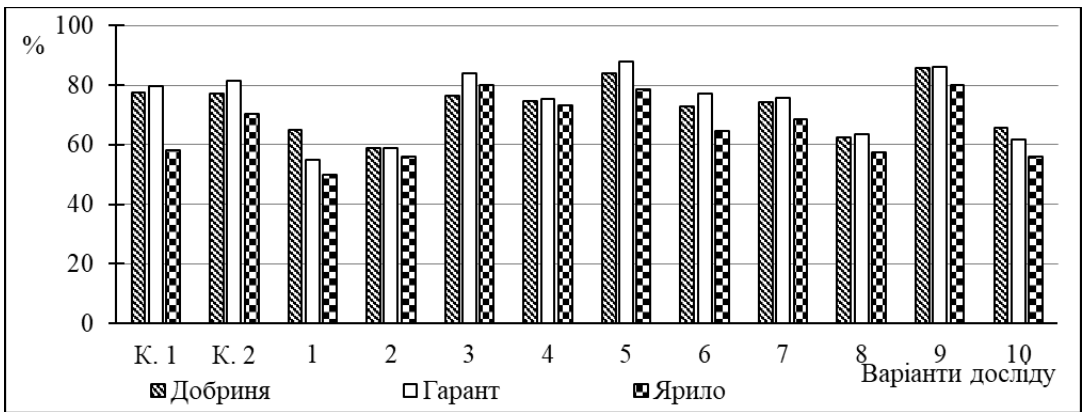

\section{II}

Рис. 1. Проліферація (I) і ризогенез (II) ініціальних експлантів винограду на різних типах поживних середовищ

\section{Література:}

1. Теслюк Н. І. Удосконалення методів культури in vitro для селекції та розмноження винограду : дис... канд. с.-г. наук : 06.01 .08 / Національний науковий центр «Інститут виноградарства і виноробства ім. В. С. Таїрова», 2009. 189 с.

2. Зеленянська Н. М. Наукове обгрунтування та розробка сучасної технології вирощування садивного матеріалу винограду : автореф. дис. ... д-ра с.-г. наук : 06.01.08. Одеса, 2016. 47 с. 